than if he were himself to offer the evidence in an action against * third person for criminal conversation. All this appears, too, in the very case of Morris vs. Miller, if we are to take observations of judges for law; for there, it is also said, that evidence of cohabitation and repute is sufficient in all cases, but indictments for bigamy, and actions for criminal conversation.

If we were to enter upon a course of fault-finding with judges, living and dead, we might blame them for saying so many things that are not law; but a more considerate view will show us, that the full force of their minds is directed to arriving at right results; and that it is too much to ask of them, that everything they siy should be said with the precision which ought to attend the text of an elementary author. But the writers of law treatises should be more careful; they have not the excuse which judges have, and they are understood to aim at greater exactness. They would exercise more care than sometimes they do, if it were not for the too prevalent, erroneous opinion, that they are entitled to shelter themselves behind the words of great judges.

J. P. B.

\title{
SELECTION OF RECENT ADJUDGED POINTS IN EQUITY.
}

Account of Back Rents-Possession against Infant.-As a general rule in cases of adverse possession, where there is no trust, no infancy, no frand, no suppression, but a mere bona fide possession, it is not the course of the Court of Chancery to carry back the account of rents beyond the filing of the bill. Pulteney vs. Warren, 6 Ves. 93; Edwoards vs. Morgan, 1 MrClel. 541. Whoever enters upon the estate of an infant, is held to have entered as bailiff or guardian, and the subsistence of the relation thus created by the entry, draws with it the right to a back account from the time of the entry into possession, though by mistake. Drummond vs The Dulee of St. Albans, 5 Ves. 433, may be considered as overruled. Hictes vs. Sallitt, 3 De Gex, Mac. \& Gord. 782.

Husband and Wife-Equity to a Settlement-Husband Foreigner domiciled abroad-Domicil whether material. -In this case a motion was made before Sir J. Stuart, V. C., that a sum of 22,623 11s. 11d., which had, in an administration suit, been carried to the separate account of a married lady-a German domiciled with her husband at Frankfort-should be paid to her husband. An affidavit was produced, to the effect that no settle- 
ment had been executed on the lady's marriage; and also an affidavit of a professor of law in Frankfort, that, in the absence of a settlement, the husband, according to the law in force there, was entitled to the fund. His honor, howrever, refused to make the order, and obserred, that "the evidence only showed, that the rights of the husband, according to the law of Frankfort, were the same as the rights of the husband, according to the law of England. The wife's equity to a settlement was an indulgence allowed by the practice of this court, in derogation of the legal rights of the husband. The evidence of the legal rights of the husband, according to the country of the domicil, had nothing to do with it."

With due deference, however, to the learned Vice Chancellor, the analogy between the merely legal rights of an English husband, and the rights of a foreign husband, seems scarcely to hold good; - because, in England, justice, as administered by Courts of Equity, forms part of the law of the land, bat not part of the law of other countries; unless, therefore (as is not the case), the law of England is applicable to the personalty in England of foreigners domiciled abroad, the analogy fails in a most material point. However, both by the practice of the court, and by the well-known prineiples of general jurisprudence, as no settlement had been made, and as, according to the law of the domicil of the husband, the personalty in question would have belonged to him, the order for payment to the husband ought to have been made. For the practice, the reader is referred to Sawyer vs. Shute, 1 Anst. 63; Campbell vs. French, 3 Ves. 323; Dues v8. Smith, Jac. 544; Anstruther vs. Adair, 2 My. \& K. 513; and Hitchcock vs. Clendinen, 12 Beav. 534; and Mr. Macqueen's valuable book on the Law of Husband and Wife, p. 79. As to the general principles upon which courts of justice deal with moveable property belonging to persons having a foreign domicil, the reader is referred to extracts from the very learned judgment of the Lord Justice Knight Bruce, when Vice Chancellor, in the case of Guepratte rs. Young, infra, next case, which exhaust the subject: one passage of Boullenois, cited by his lordship, at once disposes of the remark of the Vice Chancellor, "that the legal rights of the husband, according to the country of the domicil, had nothing to do with the question." It is as follows: "Bona mobilia sequi et regulari debent secundum statata loci domicilii ejus ad quem pertinent vel spectant." Schwabacher vs. Becker, 2 Smale \& Giff. Append. 6.

Husband and Wife-Reversionary Interest in Personalty of a Woman married to a Foreigner ḋomiciled abroad-Contract respecting, by what law governed.-A contract was entered into in England, by a married 
woman, domiciled in France, respecting her reversionary interest in trust money invested in the English Funds, which was invalid, according to the English law, on account of the property being reversionary; and although the same objection did not apply to the substance of the contract by the French law, it was not entered into in the manner prescribed by the French law, which requires that there should be as many original instruments as there are distinct parties to the contract. It was, howrever, held by Sir J. L. K. Bruce, V.C., that the French Is/ gave capacity to the married woman to enter into the contract, but that the English law regulated the form of it, and that therefore the contract was ralid, and ought to be enforced by decree. "Under the kings of France," Baid his honor; "in the seventeenth and the earlier part of the eighteenth century at least, it was I believe, a general rule of French law (at least as to moveables), that 'la loi du lieu où se passe chaque acte en régit la forme,' or, in the shorter Latin phrase, locus regit actum. Of this there seems no room for reasonable doubt. The maxim was frequently brought into action by the different laws or customs under which different parts of the kingdom were,those of Poitou, for instance, differing from those of Brittany; those of Champagne widely differing from both; while many proprietors having residences and estates in two or more provinces, were often at Paris, where a system of its own prevailed. The rule, however, I apprehend to be one, not merely of French or of English law, but one of jurisprudence (in the largest sense, at least so far as moveables and merely personal obligations are concerned), nor applied merely where there is the intervention of public fanctionaries, with reference to which it is not necessary to allode, as an instance, to the acknowledged validity of a marriage contracted in Scotland between persons domiciled elsewhere, in a manner allowed by the law of that country. There may be exceptions from special reasons in particular countries. The English law, for instance, with respect to wills of moveables, may be among them. But the existence of the rule, as a general canon of jurisprudence is, I conceive, incontrovertible. My opinion is, I repeat, with those who treat the 1325th article of the French Civil Code as not barring or obstrueting it. In the words of Modestinus,- Nülla juris ratio aut æquitatis benignitas patitur, ut quæ salubriter pro utilitate. hominum introducuntur, ea nos duriore interpretatione contra ipsorum commodum producamus ad severitatem.' I am convinced by the evidence before me, that if a French citizen, capable by the French law to contract, who is residing temporarily, but not domiciled in a country not his own, makes in that conntry, with a person there domiciled, a contract relating to 
moveables, and the contract is made in such a form, and accompanied with such ceremonies (though private only) as to render it valid and binding, according to the law of that country (applicable to persons whose capacity to contract that law recognizes), the contract binds the Frenchman wherever the moveables may be. But especially if, when the contract was made, the moveables were in the conntry where it was made, and this, though the contract be a synallagmatic contract, and the requisitions and conditions of the 1325th article be omitted and disregarded, the agreement would, therefore, if made in France, not have bound him. The proposition assumes, of course, a capacity to contract on the part of each of the contracting parties-assumes the fairness of the contract, and assumes that it does not infringe good morals, or the law, or public policy of either country; all which assumptions may, I think, with propriety and truth, be made in favor of the transaction of November, 1844; under consideration. ...... It is unnecessary to refer to Boullenois, and other well-known writers of authority on the subject, who are decisive if they can properly be invoked. But, though it is probably quite as unnecessary, I will employ a minute or two in stating three or four maxims or aphorisms, more questionable, perhaps, in point of latinity, than of any solid or important ground, which are, I believe, of general acceptance, generally true and consistent with each other in theory and practice. I mean these:-

"'Statuta suo clauduntur territorio' nec ultra territorium disponunt.

“' 'Bona mobilia sequi et regulari debent secundum statuta loci domicilii ejus ad quem pertinent vel spectant.

" 'Si lex actui formam dat inspiciendus est locus actús non domicilii.

" 'Si de solemnibus quæritur aut de modo actis ratio ejus loci habenda est ubi celebratar.'

. "I have but one superfluous word more to say before passing to another part of the case. It is notoriously of continual practice in this court to deal with the personal property of married women, domiciled elsewhere than in England, otherwise than it would be dealt with were they domiciled in England; to do so, merely by reason of the domicil. The law of the country of the domicil being attended to, a busband not domiciled here, often, as we all know, exercises powers, and obtains benefits, which an English husband could not." Guepratte vs. Young, 4 De Gex \& S. 217.

Mortgagor and Mortgagee-Power "of Sale-Notice-Infant Heir of Mortgagor.-In a mortgage deed, it was required that notice of a sale nnder the power therein contained should be given to the mortgagor, his 
heirs or assigns. The mortgagor died, leaving an infant heir. It was held, by Sir R. T. Kindersley, V. C.; that notice to the infant heir and his gaardian was good notice. Tracey vs. Laworence, 2 Drew. 403.

Mortgagor and Mortgagee-Statute of Limitations-Mortgagee in Possession-Acknowledgment of Morlgage.-A mortgagee had been more than twenty years in possession when the mortgagor's solicitor wrote to the mortgagee, on the $2 \mathrm{~d}$ of February, 1852, requesting to know when he could see him as to his claims on the mortgaged property. The mortgagee wrote a letter in reply, dated the 5th of the same month, in which he said, "I do not see the use of a meeting unless some party is ready with the money to pay me off." It was held by the Lords Justices, affirming the decision of the Master of the Rolls, that the letter of the mortgagee was a sufficient acknowledgment in writing to exclude the Statute of Limitations, although not written within twenty years after the mortgagee had entered into possession. "It appears to me," observed Lord Justice Knight Bruce, "that the writer of the letter of the 5th of February, acknowledges by it that he holds a redeemable estate in the property to which it relates, that is, that he holds it by way of mortgage. It is said, howrever, that this does not answer the requisitions of the statute, and that there is not here any acknowledgment of the title of the mortgagor, or of the right of redemption given to the mortgagor, or some person claiming his estate, or to the agent of such mortgagor or person;" and it is contended that the right of the particular person must be acknowledged. But I think that, according to the true construction of the letter of the 5th of Febraary, it must be understood as acknowledging a title to redeem in the person or persons on whose behalf the letter of the $2 \mathrm{~d}$ was written, to which the letter of the 5th was an answer. I am of opinion that the decree at the Rolls was correct, and that the appeal ought to be dismissed, with costs." Stansfield vs. Hobson, 3 De Gex, Mac. \& Gord. 620.

Mortgage of Wife's separate Estate-Presumption that Wife was Surety for Husband.-A husband and wife joined in raising money upon a mortgage of the wife's separate estate, by a deed, which stated that the money was advanced to both, and contained a covenant by the husband for payment of principal and interest. The husband having appointed his wife executrix; she paid off the mortgage debt out of the general assets, and took a re-assignment to herself of the mortgaged premises. The testator's assets being insufficient to pay his debts in full, a question was raised by a simple contract creditor whether the mortgage debt ought to have been paid in priority to his simple contract debts. It was held, by Sir W. 
Page Wood, V. C., first, that a presumption arose which might be rebutted by extrinsic evidence that the payment of the mortgage money was made to the use of the husband; secondly, that, in the absence of such evidence, the wife was only surety for her husband, and was entitled after his death, as against the other creditors, to all the rights incident to that relation, and was therefore entitled to have the mortgage paid off out of her husband's assets, as a specialty debt, in priority to his simple contract creditors. "The point," said his honor, "has never been actually decided" as between the husband's other creditors and the wife's estate; but in Tate vs. Austin, 1 P. Wms. 264; 2 Vern. 689, Lord Corper said that the wife had the right of a surety, except as against onerous creditors of her hasband, and that as against them she bad not such rights. ILord Thurlow, in Clinton vs. Hooper, 1 Ves. jun. 187; 3 Bro. C. C. 200, noticed that dictum in Tate vs. Austin, and said that he regarded the doctrine as then settled, his words being: "The rule I take to be universally this-that the title she has is precisely the same as that of an heir-at-law; because, in Tate.vs. Austin, though not the question in the cause, and consequently not weighed upon argument, yet the court was very clear that the rife oannot insist upon being paid in preference to onerous creditors." His honor, noticing that this also was a mere dictum of Lord Thurlow's, added, "It is necessary, therefore, to look at the reason of the rule, and see hor far it applies to a case where the wife's property is settled to her separate use. All the decisions on this question have been in cases in which the wife's property was not settled to her separate use, but in which the wife, having unsettled freehold property, by levying a fine or otherwise, has made a charge upon such property; and it was in reference to such a case that Lord Thurlow said, in Clinton vs. Hooper, I Ves. jun. 187, that it might seem hard upon the wife, but an assumpsit could not be raised as between her and her husband; and he said, "I have put it as between heir and executor, as the cases oblige me to put it, for the reason mentioned, because an assumpsit between husband and wife will not be raised more in equity than at law." And in commenting upon The Earl of Kinnoul vs. Money, 3 Swanst. 202, in which Lord Camden intimated a different view, because he said that the court regards the husband and wife as two distinct parties in such a case, saying, according to the note of that case in Mr. Swanston's Reports, that the court, as it were, dissolves the marriage quoad the transaction. Lord Thurlow observed, "Perhaps it is considered rather too figuratively, in saying the marriage is dissolved in that respect. That is not in Mr. Ord's note, nor any trace of it in Tate vs. Austin, and the 
other cases. They say the court will not infer an equitable assumpsit contrary to the tenor of the obligation subsisting between husband and wife, who cannot contract with each other directly without trustees."

"Whatever should ultimately be held to be the law in this respect, and I think that there will be some difficulty in supporting these dicta, although by such eminent judges, it is clear that no question as to assumpsit can exist where the estate is settled to the separate use of the wife. That is a case in which the court recognizes her as a feme sole, competent to deal with her property in every respect; and therefore an assumpsit would arise just as though she were a mere stranger. A wife, effecting a charge upon her separate property in favor of her husband, is precisely in the same position as though she had lent to him the savings of the income of such property deposited at her bankers, and which there is no doubt that he can lawfully borrow from her. She stands in the very position, with respect to her separate property, which Lord Thurlow says is too figurative a description of her position in the other case. It must be observed, however, that it is difficult to see on what other grounds, except that of an implied assumpsit, this doctrine of her right as surety ever arose. The wife is not in the mere position of the heir, for the heir cannot assert his right against legatees, but the wife can; and how she can acquire a better position than the heir, except by such an assumpsit, it is not easy to understand. Where the wife has separate estate, then, as it is laid down in Parteriche vs. Powlet, 2 Atk. 383, her separate property being applied to pay off the husband's debts, the wife must be considered as a distinct person, and is equally entitled to stand in the place of the husband's creditors as a stranger; and, according to the dictum in Robinson rs. Gee, 1 Ves. 252 , if her mortgage to secure her husband's debt is paid off out of his assets, the other creditors of the husband have no equity, in case of a deficiency of his assets, to come upon her estate.

"The choice of the mortgage creditor cannot make a distinction on any principle; and, therefore, Lord Hardwicke seems to have held, that, even in the case contemplated by Lord Thurlow in a different view, no such right can exist on the part of the general creditors. The only way in which any question as regards the right of the creditors could arise seemed to me to be, as in Copis vs. Middleton, T. \& R. 224, whether payment of the debt might not reduce the surety to the position of a simple contract creditor. However, that doctrine would not apply to a case where an executrix paid her testator's debt, because she would be entitled, independently of her rights as a surety, to be recouped out of the testator's estate, and, for that purpose, to stand in the place of the party so paid." Hudson vs. Carmichael, 1 Kay, 613. 